\title{
RESISTANCE TO ACCEPTANCE FOR IUCD, REASONS REVISITED AND EVALUATE THE ROLE OF EFFECTIVE COUNSELLING
}

\author{
Sandhya Dixit ${ }^{1}$, G. Mahalakshmi²
}

${ }^{1}$ Assistant Professor, Department of Obstetrics and Gynaecology, Osmania Medical College.

${ }^{2}$ Associate Professor, Department of Obstetrics and Gynaecology, Osmania Medical College.

\section{ABSTRACT}

\section{OBJECTIVE}

To study the reasons for refusing IUCD services in spite of the need for temporary contraception and to counsel the client into accepting it for long and short term health benefits.

\section{BACKGROUND}

India is a vast country, a sub-continent and majority of the population is young and is in the reproductive age group. It comprises of yet to be married group, married but want to postpone pregnancy group, wants to space next pregnancy group. Tubectomy operation, an excellent permanent birth control measure is not valid in the above groups. Their specific need is an effective, temporary and reversible contraception. With different failure rates and specific contraindications, many temporary methods do not suit them. IUCD is one temporary contraception, which fulfils maximum criteria needed by them. It is not only highly effective and temporary, but can be used as a long-term contraception too. In spite of its advantages, the acceptance is too low and various factors influence the same. Lack of awareness and fear of unknown is one area where counselling by one-to-one method is fruitful. Mass media usage and wide publicity may arouse the element of interest in the needy women leading to curiosity and a desire to know more about it by them. Counselling and service provision may bring in the necessary change in the attitudes of the clients.

\section{PLACE AND DURATION OF STUDY}

A study is conducted at Government Maternity Hospital, Sultan Bazaar, a teaching hospital of Osmania Medical College, Hyderabad, from January 2006 to December 2011. A total of 3080 clients who are eligible for IUCD are studied and counselled for IUCD. Clients who accepted and got IUCD inserted were followed up to 2 years.

\section{RESULTS}

Of the total of 3080 patients, only $10 \%$ agreed to IUCD insertions and about $85 \%$ refused despite counselling. Illiterate women were $68 \%$, but surprisingly $1 \%$ of the study group of professionals including doctors refused too. More than $90 \%$ are aged 25 yrs. or less constituting the potential group needing spacing method most. Rural based women are $64 \%$ and denote a large unmet need. In spite of city based, $1 / 3^{\text {rd }}$ women do not seek contraception services. There is nil knowledge regarding contraception in $67 \%$ of clients and majority come from low socioeconomic background needing urgent conduct of awareness programmes. Resistance to acceptance seen in $81 \%$, the reason being fear and misconceptions.

\section{CONCLUSION}

Lack of awareness and wrong notions are the main reasons for refusing an excellent non-hormonal, reversible and effective contraception. Calls for an urgent attention to counselling services and wide governmental publicity.

\section{KEYWORDS}

IUCD, Misconception, Spacing, Maternal Mortality, Mass Media Usage, Contraception.

HOW TO CITE THIS ARTICLE: Dixit S, Mahalakshmi G. Resistance to acceptance for IUCD, reasons revisited and evaluate the role of effective counselling. J. Evolution Med. Dent. Sci. 2016;5(41):2539-2542, DOI: 10.14260/jemds/2016/593

\section{INTRODUCTION}

Urgent need of the hour is the use of a temporary, nonhormonal, effective and long-term contraception as depicted below. India's population will reach to 1.53 billion by 2050 . Women of reproductive age group are 248 million (15 to 49). The goal of population stabilisation should occur by 2045. In spite of Government offering free IUCD services, the acceptance is very low and the percentage of IUCD usage in India is only $2 \%$.

Financial or Other, Competing Interest: None.

Submission 05-04-2016, Peer Review 30-04-2016,

Acceptance 07-05-2016, Published 23-05-2016.

Corresponding Author:

Dr. Sandhya Dixit (K. D. Sandhya Rani),

Plot 130, Sriramnagar Colony,

Near Green Water Tank,

Vanasthalipuram, Hyderabad,

Telangana.

E-mail: sandhyadixit9@yahoo.com

DOI: $10.14260 /$ jemds/2016/593
A more disturbing fact is that some women who hurry for permanent tubal ligation operation will repent later and seek recanalization services. Recanalization is a major surgery with possible restoration of tubal patency, but poor pregnancy rates. Such cases could have opted for IUCD, where the effectiveness and failure rates are comparable, i.e. 1.5\%.

\section{METHODOLOGY}

A total of 3080 women eligible for IUCD service are studied as per the following criteria.

Age, parity, rural or urban, education status, socioeconomic status, awareness and knowledge of contraception and methods, acceptance for IUCD, reasons for refusal and follow-up.

During follow-up problems and complaints noted, speculum exam was done to visualize IUCD threads, reasons for removal and user satisfaction noted.

\section{Exclusion Criteria}

- Women desiring only tubectomy operation. 
- Women with genital infections.

- Women with menorrhagic and dysmenorrhic cycles.

\section{Inclusion Criteria}

All women needing contraception and spacing of pregnancies coming to the Family Planning Outpatient Dept.

\section{RESULTS}

Of the total women counselled $(\mathrm{N}=3080)$, only 306 women accepted and got IUCD inserted.

All criteria tabulated, namely Age group, Educational status, Rural or Urban background, Parity, Awareness of contraception, Knowledge of contraceptive methods, Reasons for refusal, Follow-up problems, Reasons for removals, User satisfaction.

\section{Tabulated Results}

\begin{tabular}{|c|c|c|}
\hline $\begin{array}{c}\text { Women's response to } \\
\text { IUCD Counselling }\end{array}$ & $\begin{array}{c}\text { Number } \\
\text { Counselled }\end{array}$ & Percentage \\
\hline $\begin{array}{c}\text { Women who promptly } \\
\text { accepted IUCD }\end{array}$ & 306 & $9.94 \%$ \\
\hline $\begin{array}{c}\text { Women who expressed } \\
\text { willingness, but did not } \\
\text { return for IUCD }\end{array}$ & 277 & $8.99 \%$ \\
\hline $\begin{array}{c}\text { Women who refused } \\
\text { despite counselling }\end{array}$ & 2497 & $81.07 \%$ \\
\hline Total Women Counselled & $\mathbf{3 0 8 0}$ & $\mathbf{1 0 0 \%}$ \\
\hline \multicolumn{2}{|c|}{ Table 1: Acceptance of IUCD } \\
\hline \multicolumn{2}{|c|}{} \\
\hline
\end{tabular}

\begin{tabular}{|c|c|c|}
\hline Educational Qualification & Number & Percentage \\
\hline Illiterate & 2108 & 68.46 \\
\hline $\begin{array}{c}\text { Less than SSC } \\
\text { (Can write their names) }\end{array}$ & 828 & 26.89 \\
\hline SSC/Intermediate & 47 & 1.53 \\
\hline Graduates & 57 & 1.85 \\
\hline $\begin{array}{l}\text { Postgraduates and } \\
\text { professionals }\end{array}$ & 39 & 1.27 \\
\hline Total & 3080 & $100 \%$ \\
\hline \multicolumn{3}{|c|}{ Table 2: Educational Status } \\
\hline
\end{tabular}

Majority of women are illiterate or school dropouts and are amenable for counseling and awareness programs in mass media.

\begin{tabular}{|c|c|c|}
\hline Age Group & Number & Percentage \\
\hline$<20$ years & 1207 & 39.19 \\
\hline $21-25$ years & 1710 & 55.52 \\
\hline $26-30$ years & 112 & 3.64 \\
\hline $31-35$ years & 31 & 1.0 \\
\hline$>35$ years & 20 & 0.65 \\
\hline Total & $\mathbf{3 0 8 0}$ & $\mathbf{1 0 0 \%}$ \\
\hline \multicolumn{3}{|c|}{ Table 3: Age Group } \\
\hline
\end{tabular}

Majority women were less than 25 years of age and under the influence of family, neighbourhood and misconceptions.

Though small in size, women above 35 years still did not use any contraception before our counselling. Obviously pregnancies would be unwanted in them and seeking MTP services, associated morbidity, cost, hospital burden and mortality would be more in them.

\begin{tabular}{|c|c|c|}
\hline Background & Number & Percentage \\
\hline Rural based women & 1978 & 64.22 \\
\hline Urban area women & 1102 & 35.78 \\
\hline Total Women & 3080 & $100 \%$ \\
\hline
\end{tabular}

In spite of living in urban areas and accessibility, $1 / 3^{\text {rd }}$ of women had no contraception either for lack of awareness or knowledge.

There is a large unmet need in rural areas.

\begin{tabular}{|c|c|c|}
\hline Socio Economic Status & Number & Percentage \\
\hline Low socioeconomic group & 1991 & 64.64 \\
\hline Middle class group & 1004 & 32.60 \\
\hline High income group & 85 & 2.76 \\
\hline Total & 3080 & $100 \%$ \\
\hline
\end{tabular}

Almost $60 \%$ belong to low socioeconomic group, but $1 / 3^{\text {rd }}$ of the study group are middle class and come to government facilities for health related issues. Therefore, counselling opportunities are aplenty.

\begin{tabular}{|c|c|c|}
\hline Awareness of IUCD & Number & Percentage \\
\hline Nil knowledge & 2081 & 67.56 \\
\hline Vague knowledge and sceptical & 902 & 29.29 \\
\hline $\begin{array}{l}\text { Awareness and knowledge of } \\
\text { method and place of service } \\
\text { provision }\end{array}$ & 97 & 3.15 \\
\hline $\begin{array}{l}\text { Total } \\
\end{array}$ & 3080 & $100 \%$ \\
\hline \multicolumn{3}{|c|}{$\begin{array}{l}\text { Table 6: Awareness of IUCD as a } \\
\text { Temporary Contraception }\end{array}$} \\
\hline
\end{tabular}

Absolute lack of knowledge in $2 / 3^{\text {rd }}$ of potential clients call for an urgent awareness programmes in mass media, grass root level sensitization by field staff, coordinated service programmes where all national programme counsellors add this in their list of counselling.

\section{Counselling Methods for the Study Group}

Individual, family and group counselling done. Details of the procedure, need for regular follow-up, assurance of prompt service for any problem and emphasising on reversal of reproduction explained to them in easy words.

\begin{tabular}{|c|c|c|}
\hline $\begin{array}{l}\text { Reasons Given for Refusing } \\
\text { IUCD Service }\end{array}$ & Number & Percentage \\
\hline Fear of the unknown (scared) & 1824 & 59.22 \\
\hline Misconceptions & 673 & 21.85 \\
\hline $\begin{array}{l}\text { Failed to return for IUCD } \\
\text { service after agreeing to it }\end{array}$ & 277 & 8.99 \\
\hline Total number refused & 2774 & 90.06 \\
\hline Accepted IUCD & 306 & 9.94 \\
\hline Total women counselled & 3080 & $100 \%$ \\
\hline \multicolumn{3}{|c|}{ Table 7: Reasons Given for Refusing IUCD Service } \\
\hline
\end{tabular}

\begin{tabular}{|c|}
\hline Migrates upwards resulting in vital organ damage \\
\hline May cause pricking pain in the uterus throughout \\
\hline Cause pain and hurt the husband during coitus \\
\hline Poisoning of the uterus and body \\
\hline Causes weakness and incapacity \\
\hline Unfit for coitus \\
\hline Infertility and ectopic pregnancy \\
\hline Table 8: Myths \& Misconceptions \\
\hline
\end{tabular}


The source of misconceptions includes family members, friends, neighbourhood women and some health personnel themselves.

\begin{tabular}{|c|c|c|}
\hline IUCD Acceptors & Number & Percentage \\
\hline Voluntary and fully aware & 109 & 3.54 \\
\hline Fruitful counselling & 101 & 3.28 \\
\hline Post abortal & 85 & 2.76 \\
\hline Emergency contraception & 11 & 0.36 \\
\hline $\begin{array}{l}\text { IUCD acceptors total no. of } \\
\text { women }\end{array}$ & 306 & 9.94 \\
\hline $\begin{array}{l}\text { Total number of women refused } \\
\text { IUCD }\end{array}$ & 2774 & 90.06 \\
\hline Total Women Counselled & 3080 & $100 \%$ \\
\hline \multicolumn{3}{|c|}{ Table 9: IUCD Acceptors Total of 306 Women } \\
\hline
\end{tabular}

Counselling worked in $1 / 3^{\text {rd }}$ acceptors. Next group are post-abortal, where fear of unwanted pregnancy made it easy for counselling.

\begin{tabular}{|c|c|c|}
\hline $\begin{array}{c}\text { Overlapping Problems-IUCD } \\
\text { Follow-up }\end{array}$ & Number & Percentage \\
\hline Removals & 111 & 36.28 \\
\hline Expulsions (Spontaneous) & 9 & 2.94 \\
\hline Migration to peritoneal cavity & 2 & 0.65 \\
\hline Menorrhagic cycles & 76 & 23.84 \\
\hline Menstrual pain lower abdomen & 23 & 7.52 \\
\hline Pregnancy with in situ IUCD & 2 & 0.65 \\
\hline $\begin{array}{c}\text { Still using IUCD despite minor } \\
\text { problems at the conclusion of } \\
\text { the study period }\end{array}$ & 182 & 59.48 \\
\hline $\begin{array}{c}\text { Table 10: IUCD Follow-up (Overlapping } \\
\text { Problems) Total Acceptors 306 }\end{array}$ \\
\hline
\end{tabular}

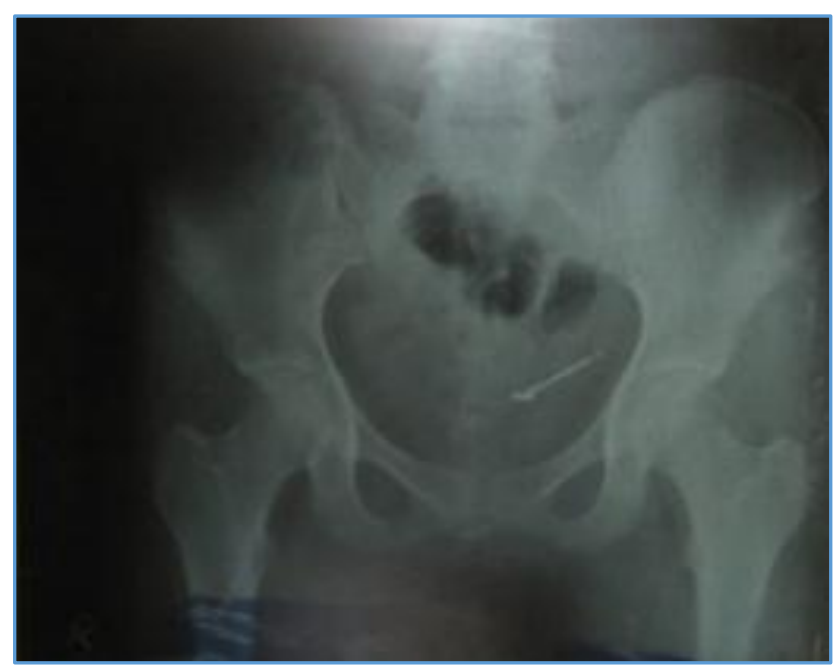

Copper T in the Peritoneal Cavity - Rare Complication

\begin{tabular}{|c|c|}
\hline Reasons for Removal & Number \\
\hline Desire for pregnancy & 61 \\
\hline Persistent pain & 15 \\
\hline AUB & 22 \\
\hline Spouse pressure & 13 \\
\hline \multicolumn{2}{|c|}{ Total Removals } \\
\hline \multicolumn{2}{|c|}{ Table 11: Reasons for Removal 111 } \\
\hline
\end{tabular}

\begin{tabular}{|c|c|}
\hline User Satisfaction & Number \\
\hline Satisfied & 274 \\
\hline Non-committal, but continue to use it & 21 \\
\hline Not Satisfied & 11 \\
\hline Total & $\mathbf{3 0 6}$ \\
\hline Table 12: User Satisfaction \\
\hline
\end{tabular}

\section{DISCUSSION}

IUCD is a reversible, non-hormonal, long term and very effective, $98.5 \%$ temporary contraceptive method. Best for spacing of pregnancies by 24 months as per the WHO guidelines in Healthy Spacing and Timing of Pregnancies. Two to three years of gap between pregnancies brings down maternal and perinatal mortalities. Infant and neonatal mortalities are reduced too.

\section{IUCD usage in India vs other methods}

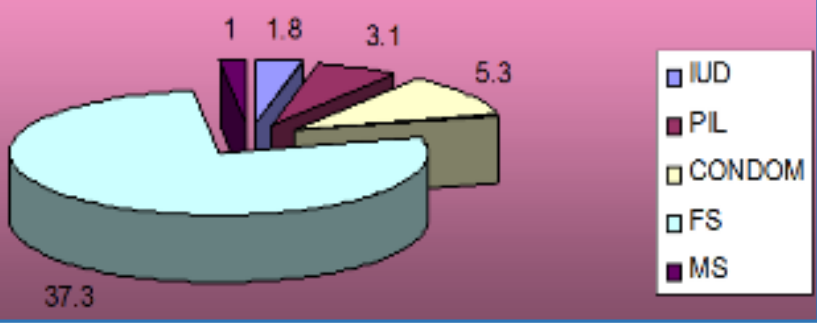

IUCD Usage in India vs Other Methods Ref: NFHS-3 (2005-2006)

Contraceptive Efficacy of Various Methods

Very Effective

Pregnancy rates between 0-1 per 100 women in first year of use. IUCD belongs to this group.

\section{Effective}

Pregnancy rates between 2-9 per 100 women in first year.

\section{Somewhat Effective}

Pregnancy rates between $10-13$ per 100 women in first year of use.

\section{Advantages of IUCD Method of Contraception}

- Reversible, very effective, non-hormonal and long-term (Up to 5 to 10 years).

- High safety profile.

- No influence on breast feeding.

- Coital and partner independent.

- No drug interaction.

- One time procedure.

- $\quad$ Return to fertility within 3 months.

Can be used in cases not suitable for tubectomy operation namely anaemia, superstitions for permanent sterilisation, refusal of tubectomy on religious grounds, few medical disorders where surgery is contraindicated. 


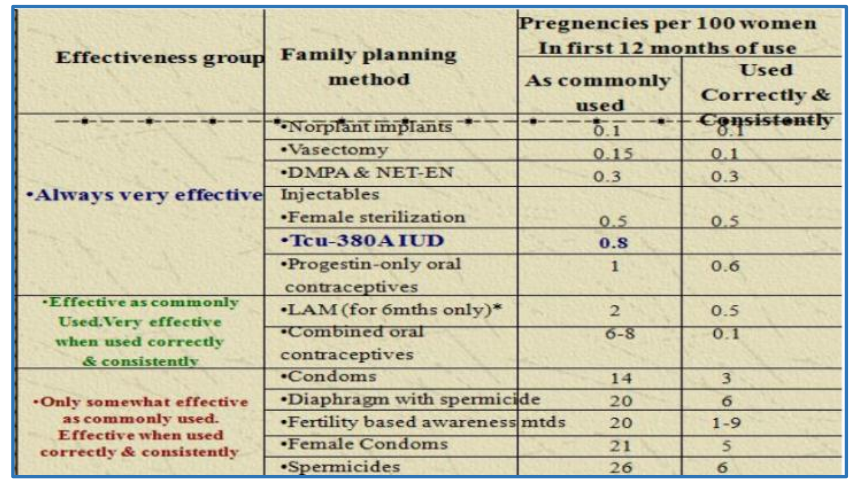

Effectiveness of Various Contraceptive Methods

Adequate spacing of next pregnancy allows for restoration of health in the mother, prevents anaemia and allows adequate lactation for the first baby including good care and reduction in child mortality. Removal of fear of unwanted pregnancy improves women's well-being, marital harmony and social upheaval.

In our study acceptance is only $9.9 \%$, but in a study conducted at Lagos University Teaching Hospital.(1) the author's results show $58.17 \%$ accepted IUCD. In a study conducted in a teaching hospital in Nigeria,(2) authors concluded that IUCD is a safe and effective contraceptive method with a high acceptability 55.4\%.

The Cochrane Collaboration 2012, Issue 3.(3) strategies for improving the acceptability and acceptance of the copper intrauterine device (Review), the authors noted that Intrauterine Devices (IUDs) are highly effective, most widely used reversible contraceptive method in the world. But they also noted that in developed countries, IUDs are among the least common method. They summarized that use of copper IUDs are low in countries with relatively high rates of unintended pregnancies. The authors concluded that community-based interventions and antenatal contraceptive counselling improved uptake of copper IUD contraception.

A study done at Scotland.(4) showed that myths that it may move around in the body $23.8 \%$ and painful insertion $34 \%$. Authors concluded that lack of knowledge of the method is also evident.

In an article from United States.(5) authors noted that myths, misperceptions and barriers to use-Several factors have limited widespread use of the IUD in the US including a history of negative publicity; misinformation regarding the risks of infection, ectopic pregnancy and infertility; misinformation about eligible candidates for IUD use; misconceptions about the mechanism of action of the IUD; lack of clinician training; and fears of litigation.(6)

\section{CONCLUSION}

Lack of awareness and wrong notions are the main reasons for refusing IUCD, which is an excellent long-term non-hormonal, reversible and effective contraception.(7) Calls for an urgent attention to counselling services and wide governmental publicity.

\section{SUGGESTIONS}

Mass media and communication through celebrities, documentaries, short films and a compulsory slogan regarding IUCD during all small and big screen films and serials must be considered on war footing.

- Mass drive for recruitment of counsellors.

- Incentives for service providers.

- Regular and fixed IUCD fortnight camps.

- All tubectomy camps should simultaneously conduct IUCD camps alongside.

- Those unfit for tubectomy can benefit through IUCD insertion.

- $\quad$ Training of health personnel for counselling and for skill of insertion techniques should be taken up.

- Rename tubectomy camps as Contraception Camps. All varieties of contraception should be made available including trained service providers on that day. Different facilities should have fixed day contraception camps.

\section{REFERENCES}

1. Adegbola 0 , Ogedengbe $\mathrm{OK}$. The acceptance rate of intrauterine contraceptive device (IUCD) among family planning clinic users in Lagos University Teaching Hospital (LUTH). Nig Q J Hosp Med 2008;18(4):175-80.

2. Olatinwo $\mathrm{AW}$, Anate $\mathrm{M}$, Balogun $\mathrm{OR}$, et al. Intrauterine contraceptive device (IUCD): sociodemographic characteristics of acceptors, acceptability and effectiveness in a teaching hospital in Nigeria. Niger J Med 2001;10(1):14-7.

3. Arrowsmith ME, Aicken CRH, Saxena S, et al. Strategies for improving the acceptability and acceptance of the copper intrauterine device. Cochrane Database Syst Rev 2012;3. http:/www.thecochranelibrary.com

4. Michie L, Cameron ST, Glasier A, et al. Myths and misconceptions about intrauterine contraception among women seeking terminationhof pregnancy. J Fam Plann Reprod Health Care 2014;40(1):36-40. doi: 10.1136/jfprhc-2012- 100497.

5. Libby Levine. The IUD rumor mill: Common misconceptions. Clinical Advisor 2015;1-4.

6. Gillian Dean, Alisa B Goldberg. Intrauterine contraception: devices, candidates, and selection. Up To Date 2016.

7. How to Deal with Rumors and Misconceptions about IUDs.

https://www.k4health.org/sites/default/files/Service\% 20Delivery_rumorsandmisconcept.pdf 